Ewa Danowska

Uniwersytet Jana Kochanowskiego w Kielcach

\title{
Rabacja chłopska 1846 roku w relacji ks. Jana Popławskiego z Niegowici
}

\author{
Najprzód donoszę Ci, żem żywy, bo tu w naszych okolicach \\ nie każdy tym poszczycić się może... ${ }^{1}$.
}

Wypadki z 1846 roku określane mianem rabacji dotyczyły zachodniej Galicji, głównie okolic Tarnowa, Bochni i Jasła. Po tych krwawych wydarzeniach zrodziły się dwie wersje ich oceny: urzędowa (austriacka) i patriotyczna (polska). Ta pierwsza wersja przedstawiała rzeź galicyjską jako odruch wierności włościan wobec monarchii austriackiej, potępiających próbę powstania przeciw cesarzowi. Z polskiej strony rabację potraktowano jako skutek świadomej prowokacji dokonanej przez biurokrację austriacką, która poszczuła chłopów na powstańców i szlachtęe 2 .

Rok 1846 w szczególny sposób zapisał się w polskich dziejach. Był rokiem wielkich nadziei związanych z przygotowywanym od kilkunastu lat powstaniem narodowym, a okazał się rokiem wielkiej narodowej tragedii. Rabacja chłopska położyła się ponurym cieniem na naszej historii ${ }^{3}$.

Grupy spiskowców przygotowujących powstanie narodowe w Galicji, w zaborach pruskim i rosyjskim, przygotowywali się na oznaczony przez Ludwika Mierosławskiego dzień wybuchu - 21 lutego 1846 roku - w trzech zaborach jednocześnie. Walka miała łączyć cechy wojny partyzanckiej i rewolucji społecznej.

${ }^{1}$ Jędrzej Rogojski właściciel Lubli w jasielskiem, do brata we Lwowie, w: Rok 1846 w Galicji. Materiały źródłowe. Zebr. i oprac. J. Sierawski, C. Wycech. Warszawa 1958, s. 246.

2 S. Grodziski, Rok 1846 w Galicji. Przyczyny i konsekwencje. „Rocznik Bocheński” R. 4: 1996, s. 7. Zob. też: tenże, Wstęp. W: L. Żuławski, Oblężenie Limanowy czyli rzeź galicyjska 1846 wierszem i inne utwory. Oprac. J.M. Dziewulska, wyd. J. Żuławski. Kraków 2010, s. 7-16.

${ }^{3}$ F. Ziejka, Misjonarz wśród rabantów. W: Rok 1846. Ludzie, wydarzenia, tradycje. Zbiór studiów. Pod red. M. Śliwy. Kraków 1997, s. 65. 
Od roku 1845 dwaj najaktywniejsi emisariusze - Edward Dembowski i Julian Goslar rozwijali na ziemiach polskich powstańczą propagandę. Obaj byli optymistycznie nastawieni, chociaż agitacja demokratyczna na wsi szła opornie. Hasła polityczne do chłopów nie przemawiały, ideał państwa polskiego był im obcy, bo „pański”, nie wierzyli w zniesienie pańszczyzny i donosili do cyrkułów na buntujących się panów. Co więcej, na wsi szerzyła się absurdalna wieść, że panowie knują na zgubę chłopów, których będą „wyrzynać”. Powstańcy obawiali się raczej bierności chłopów, natomiast nie spodziewali się ich wrogiego wystąpienia. Nie doceniali znaczenia i wpływów austriackiej biurokracji na galicyjską wieś. Zamiar powstania narodowego nie udał się. W nocy z 18 na 19 lutego, przyspieszając jego datę, spiskowcy próbowali atakować w kilku miejscowościach. Pod kierunkiem majora Leona Czechowskiego zamierzali opanować Tarnów, ale na drodze obok żołnierzy austriackich stanęli chłopi uzbrojeni w cepy, widły i kosy. W Tarnowie starostą był Joseph Breinl, który postanowił wykorzystać naturalnego przeciwnika polskiej szlachty, jakim był chłop pańszczyźniany. Na 18 lutego 1846 roku zwołał do Tarnowa zebranie wójtów i najbardziej radykalnych przedstawicieli chłopstwa Za obietnicę rychłej poprawy ich sytuacji polecił im, aby rozbrajali powstańców i odsyłali ich żywych lub martwych do siedziby cyrkułu. Breinl utwierdzał chłopów w przekonaniu, że władze nie będą im przeszkadzać w rozprawieniu się z odwiecznymi wrogami i ciemiężcami - ich panami. Już 19 lutego watahy „czerniawy” rozpoczęły na szeroką skalę zbrojenie się, wystawianie wart na gościńcach, rozbrajanie zbierających się oddziałów szlacheckich, napadanie na dwory, rabowanie i mordowanie szlachty folwarcznej oraz jej oficjalistów. W Tarnowskiem, Nowosądeckiem i w części Jasielskiego chłopi wdzierali się do dworów pod pretekstem szukania powstańców i broni. Bunt chłopów nazwany był rabacją, od niemieckiego słowa Raub - rabunek. W dworach i plebaniach niszczyli sprzęty, rekwirowali ziarno i trzodę, usuwali też dokumenty określające ich obowiązki względem dworu. Chłopi bili i mordowali właścicieli, ich rodziny, oficjalistów oraz służbę dworską. W samym powiecie tarnowskim w ciągu trzech dni dokonano pogromu w ponad 90 proc. dworów. Łącznie zginęło około 1000 osób, z tego 200 właścicieli ziemskich. Były to „krwawe zapusty”. Chłopi, czyli tzw. „czerniawa”, nie byli zorganizowani, a poza Jakubem Szelą nie mieli innych przywódców. Szela był włościaninem z miejscowości Smarzowa w Tarnowskiem, przez lata pełnomocnikiem chłopów w przegrywanych procesach sądowych z dziedzicem Wiktorem Boguszem z Siedlisk, który stał się jedną z pierwszych ofiar rabacji - Szela bowiem poprzysiągł mu zemstę. Postanowił, że kiedy zawiodły sądy, rachunki z dworem należy uregulować kosą, cepem i siekierą. Tylko jednego dnia, 20 lutego, jego ludzie zamordowali 23 osoby. Pozycję 
Jakuba Szeli jako lokalnego przywódcy uznawało około 50 wsi. Zamyślał o utworzeniu ludowych sądów, organizował warty wiejskie, wystąpił do Gubernium we Lwowie z prośbą o zmniejszenie pańszczyzny i przyznanie wsi licznych ulg. Władze austriackie nie widziały jednak takiej potrzeby. Początkowo Austriacy wyraźnie zachęcali chłopów do gwałtownych poczynań. Administracja wypłacała im gratyfikacje za zabitych bądź pojmanych powstańców - według taksy starosty Breinla za ujętego domniemanego powstańca chłopu należało się 5 reńskich, a za zabitego - 10. Częstowano też „dzielnych chłopów” wódką. Płaciła władza austriacka, a to oznaczało legitymizację rabacji. Natomiast po pewnym czasie, w obawie aby rabacja nie przekształciła się w powstanie chłopskie, zaczęła przeciwdziałać poprzez aresztowania chłopów i karę chłosty. Należy zauważyć, że po raz pierwszy w dziejach Polski w 1846 roku nastąpiła na tak wielką skalę próba fizycznego zniszczenia szlachty przez chłopów. Od lat narastał bowiem sprzeciw chłopów wobec systemu pańszczyźnianego. Antyszlacheckie nastroje podgrzewali niektórzy radykalni demokraci, a z drugiej strony administracja austriacka zaniepokojona konspiracją niepodległościową. W lutym 1846 roku chłopi nie mieli wątpliwości, że panowie podnieśli rękę na cesarza i władzę. Byli przekonani, że zmiana stosunków na wsi może dokonać się tylko z woli cesarza. Można uznać, że zwycięzcami rabacji byli nie chłopi, ale Austriacy, którzy poróżnili oba stany, umocnili wiarę chłopów w sprawiedliwego cesarza i przekonali Europę, jak niebezpieczni są polscy spiskowcy. Natomiast polscy demokraci stracili wiarę w ukochany przez siebie lud ${ }^{4}$.

W relacji Józefa Nocka: Co opowiadali ojcowie o rabacji w roku 1846 zawarty został opis nastrojów wśród chłopstwa, jakie panowały na początku 1846 roku: „Gdy wnet miała nastąpić rabacja, szły wieści po wsi, że «panowie będą chłopów rżnąć, aby każdy przygotował widły, cepy i kosy i nie dał się panom zarżnąć». Strach padł na ludzi i kopali jamy z dala od domów i tam miano się chować, gdy ten dzień nadejdzie. Kto to mówił pierwszy, nikt nie wiedział - ogólnie mówili wszyscy"s.

4 A. Chwalba, Historia Polski 1795-1918. Kraków 2000, s. 301-303; J. Zdrada, Historia Polski 1795-1914. Warszawa 2007, s. 334-341; W. Hop, Jakub Szela - krwawy upiór czy obrońca chłopów? Wokół rabacji chłopskiej 1846 r. - prawda i mity. „Rocznik Jasielski” R. 6: 2006, s. 10-11, 13. S. Schnür-Pepłowski podaje, iż w Tarnowie płacono za trupa szlachcica pierwszego dnia rzezi 20 złotych reńskich, drugiego dnia 10 złr, trzeciego - 5 złr. Gdy później zaprzestano dawania zapłaty, chłopi porzucali zwłoki pomordowanych w przydrożnych rowach. Zob. S. Schnür-Pepłowski, Z przeszłości Galicyi (1772-1862). Lwów 1895, s. 433.

5 Rok 1846 w Galicji. Materiały źródłowe..., s. 362. 
Bolesław Limanowski, galicyjski socjalista, autor licznych prac historycznych i socjologicznych uważał, że rabacja była dziełem biurokracji austriackiej, która już na początku roku 1846 zaczęła straszyć chłopów i podburzać przeciwko panom. Rozpuszczano pogłoski, że cesarz chce znieść pańszczyznę, a panowie się temu sprzeciwiają i przygotowują do buntu ${ }^{6}$. Limanowski pisze dalej: „Najważniejszą przyczyną rzezi galicyjskiej była straszna ciemnota chłopów. Gdyby w ich głowach było nieco jaśniej, czyżby uwierzyli w tak niedorzeczną pogłoskę, rozpuszczoną przez sługusów rządowych i propinatorów żydowskich, że szlachta miała wyrzynać chłopów?! Cóżby robiła wówczas szlachta ze swoją ziemią? Nie przychodziło im do głowy i szczerze wierzyli w bezmyślną pogłoskę. [...] Chłopi mścili się na ciarachach, bo tak nazywali szlachtę, za krzywdy swoje, za ciężką pańszczyznę, za uwodzenie żon i córek. W ciemnocie swojej nie wiedzieli jednak, że ci, co byli najgorsi dla nich, trzymali właśnie z rządem, pouciekali do Wiednia, do Lwowa pod osłoną wojska austriackiego"7.

Starosta Joseph Breinl w jednym ze swoich pierwszych raportów, 22 lutego 1846 roku informował: „każda gmina nie u swych własnych państwa, ale u sąsiednich rewiduje, zabiera wszystkich bez różnicy, a w razie oporu rani i zabija”. Tak zatem na ogół chłopi czynili szkody i krzywdy w sąsiednich dworach. Austriacy zrzucali w ten sposób winę za ekscesy na jakieś obce, nieodpowiedzialne elementy, szlachta zaś argumentowała, że skoro chłopi napadali tylko na cudzych panów, to oczywiste, że do własnych nie mieli pretensji. Tłum wolał mordować w obcym dworze, by ofiary nie mogły rozpoznać twarzy swoich morderców. Jedno z austriackich źródeł mówi o „interesie wymiennym”, jakie zawierały wyręczające się w pogromach gminy. Oczywiście sytuacja taka nie była stałą regułą. Większość relacji zarówno szlacheckich, jak i urzędniczych mówi o tłumie chłopów, nie określając, czy przeważali w nim kmiecie, czy zagrodnicy. Jednakże zarówno źródła polskie, jak i austriackie podkreślają zgodnie przodujący udział urlopników w rzezi. Byli to chłopi wyćwiczeni w służbie dla cesarza, bywali w świecie, pozbawieni lęku przed dziedzicem. Niektóre ze świadectw obok urlopników jako przodowników rzezi wymieniają także dziadów proszalnych i kryminalistów. Co więcej, udział w napadach i rabunkach brali także zamożniejsi gospodarze, często przewodząc swoim parobkom ${ }^{8}$.

6 B. Limanowski, Historja ruchu rewolucyjnego w Polsce 1846. [b.m. i r.], s. 160.

Tamże, s. 167-168.

8 S. Kieniewicz, Ruch chłopski w Galicji w 1846 r. Wrocław 1951, s. 197, 199-201. 
W czasie zapustów 1846 roku chłopi mordowali i obrabowywali nie tylko znienawidzonych panów, ale i księży, leśniczych, pisarzy gminnych, ekonomów, rządców, karbowych, guwernerów i innych oficjalistów w służbie dworskiej, a także tych chłopów, którzy odważyli się stanąć w obronie napadniętych ${ }^{9}$. Chłopi dopuszczali się gwałtów również na osobach księży, np. w Tarnowskiem czterech zostało zamordowanych, wielu poturbowanych, a plebanie okradzione i zdemolowane. Prawie nigdzie księdzu nie udało się zapobiec rzezi, nawet wtedy, gdy zastępował drogę tłumowi z Przenajświętszym Sakramentem. Krążyły pogłoski, że cesarz skasował dziesięcioro przykazań, chłopi wchodzili do kościołów i klasztorów w czapkach i z fajkami, wjeżdżali konno, niszczyli krucyfiksy, obrazy i sprzęty. O sprawach religijnych mieli osobliwe pojęcie, idąc np. po rozgrzeszenie za morderstwo, które mieli popełnić, czy żądając, by ksiądz odprawił mszę „za szczęśliwie dokonaną rabację”. Jednakże kościoły w porównaniu do dworów wyszły z pogromu obronną ręką, bo niszczenie rezydencji szlacheckich było powszechne. Tłum rujnował je nawet tam, gdzie nie zabijał właścicieli. Cepami gromady potłuczone zostały szyby w oknach, lustra, żyrandole, zegary. Rąbano meble i podłogi, rozwalano piece i ściany w poszukiwaniu ukrytych kosztowności, niszczono biblioteki i akta związane z prowadzeniem majątku, ogołacano spiżarnie i spichrze, zabierano zwierzęta dworskie. Chłopi w dziele zniszczenia nie pomijali także oranżerii, ogrodów i parków ${ }^{10}$.

Jędrzej Rogojski właściciel Lubowli w Jasielskiem, w liście do brata we Lwowie opisał, jak poturbowali go chłopi, „a tymczasem drudzy wpakowali się do pokojów, porozbijali wszystkie zamknięcia i co tylko wódki, wina, kiełbas, szynek w momencie konsumowali, co się zaś tyczy bielizny, sukien, itd. dużo pozabierali. Trwał ten rozgardiasz dobre dwie godziny. [...] Kto by się spodziewał, że chłop nasz taki dziki i krwiożerczy? Księżom także nie darowali, każden zrabowany, religia w pośmiewisku, pytają się, czy Pan Bóg słomiany czy drewniany, trafiało się, że w kościele fajki palili”"1.

Warto zwrócić uwagę na kronikarski zapis wydarzeń rzezi galicyjskiej uwieczniony przez siedemnastoletnią wówczas Mariannę Pikuzińską (18291906). Wraz z matką mieszkała w dworze w Dołędze, leżącym $35 \mathrm{~km}$ od Tarnowa. Nieopodal osiedlił się jej brat Teofil z rodziną, który zginął z rąk chłopów

9 F. Ziejka, Misjonarz..., s. 66.

10 S. Kieniewicz, Ruch chłopski..., s. 216-222.

${ }^{11}$ Rok 1846 w Galicji..., s. 246. 
podczas rzezi galicyjskiej, będąc poza domem. Okoliczności jego śmierci i dokładna data wyszła na jaw dopiero po wielu latach. 20 lutego 1846 roku Marianna zanotowała: „Chłopi trzymają wartę po gościńcach, nie puszczają nikogo, zamiast pomagać, przeszkadzają. Co się będzie działo! Boże zlituj się!”2. Pięć dni później, 25 lutego Marianna napisała w swoim pamiętniku: „Wściekłe hordy z cepami, widłami, napadają bezbronnych, biją, mordują, odwożą do cyrkułów, a tam im płacą. O! przeklęci, na wieki przeklęci, w których głowach rozwinął się ten pomysł. Ale nie - to niepodobna, aby człowiek, chrześcijanin, mógł coś podobnego wymyślić, samo piekło musiało im [to] poddać. Tak obłąkać ciemne umysły tylu ludzi, porobić ich zbójami, mordercami swoich braci, swojej Ojczyzny - to okropne. Jak oni są ciemni, jak poprzewracane mają w głowach, że to ich panowie mieli zabijać. O Boże, za co nas tak karzesz?"'s. Dalej siedemnastoletnia Marianna opisuje, jak na dwór w Dołędze napadła gromada z Zaborowa. W czasie rewizji chłopi dokonali wielu zniszczeń, nazywając jego mieszkańców rebeliantami. Jak uważa pamiętnikarka, ucieczka byłaby ryzykowna, gdyż uciekających chłopi pojmowali lub zabijali ${ }^{14}$. Oddajmy jeszcze raz głos Mariannie, która 30 marca tak oceniała szanse planowanego powstania narodowego i rolę chłopów: „Żeby nie chłopi wszystko byłoby dobrze poszło. Tak mało wszędzie było wojska i to tak strwożone, że byliby uciekali jak zające i poddawali się wszędzie. Ale ta głupota, ta zapamiętałość wściekła, tyle nieszczęść sprowadziła na kraj. Czemuż oni tak ciemni? I nic nie rozumieją"15.

Ofiar rzezi galicyjskiej nikt nie zdołał dokładnie policzyć, wahają się one od 200 aż do 2 tys. osób. Stefan Kieniewicz, zestawiając różne wykazy imienne, doliczył się 639 nazwisk. Jest to liczba z całą pewnością niepełna. Na przykład, na 146 trupów zwiezionych do Tarnowa tylko 30 udało się rozpoznać. W Tarnowie i Bochni, gdzie w okolicy pogromy były najliczniejsze, biurokraci austriaccy liczyli tylko tych pomordowanych, których przywieziono do cyrkułu. Spośród ustalonych przez S. Kieniewicza 639 osób, 424 przypada na Tarnów, 69 na Bochnię, 19 na Nowy Sącz, 14 na Jasło, 8 na Sambor, 3 na Sanok i jedna na Rzeszów. W 101. przypadków pomordowanych osób, nie udało się

12 Rabacja na Powiślu. Dziennik Marianny Pikuzińskiej i relacje chłopskie o krwawych wydarzeniach 1846 r. Oprac. K. Bańburski, W. Konieczny. Tarnów 2006, s. 8, 31.

13 Tamże, s. 31.

14 Tamże, s. 31-32.

15 Tamże, s. 35. 
ustalić, skąd one pochodziły. Aresztowano natomiast szacunkowo około 3 tys. osób ${ }^{16}$. Według danych zebranych urzędową drogą, ofiarą rabunku padło około 140 dworów w Tarnowskiem, 100 w Bocheńskiem, 92 w Sądeckiem, 69 w Jasielskiem, 25 w Sanockiem. Niewykluczone, że dane te należałoby podwyższyć17.

O wiele trudniej jest oszacować, jaki procent galicyjskiej szlachty został dotknięty rabacją chłopską. Historycy badający dzieje społeczne Galicji różnie oceniali liczebność stanu szlacheckiego. Walerian Kalinka obliczył, że w 1817 roku Galicję zamieszkiwało 31 tys. osób zaliczanych do szlachty, natomiast Irena Rychlikowa oceniła jej liczebność na ok. 3 proc. ogółu ludności. Jej rozmieszczenie różnie się kształtowało, np. w cyrkule samborskim szlachta stanowiła aż 12 proc. ludności, a w bocheńskim, myślenickim czy sądeckim - tylko 1,5 procent. Według najnowszych badań liczba szlachty w Galicji mieściła się w przedziale między 70 a 120 tys. osób ${ }^{18}$.

Po chłopskiej rabacji społeczeństwo polskie okryło się żałobą. Więzienia nie mogły pomieścić całej masy aresztowanej szlachty, na areszty przerabiano nawet klasztory i domy prywatne. Kobiety ukazywały się na ulicach w ciężkiej żałobie, gdyż niemal każda rodzina straciła kogoś z bliskich. Obraz wsi galicyjskich w 1846 roku stanowiły spalone i zniszczone dwory i budynki gospodarskie. Wielu mieszkańców owych dworów szukało schronienia w miastach. W tym to czasie powstał słynny chorał Kornela Ujejskiego $Z$ dymem pożarów, „który od tej pory uderza w niebiosa”. Natomiast w lipcu 1846 roku starostowie: bocheński, przemyski, wadowicki, sądecki i jasielski przedstawieni zostali do nagrody, także austriackie władze wydały liczne pochwały dla wójtów i gromad ${ }^{19}$.

Niektórzy z historyków i publicystów wyznający konserwatywne zasady życia społecznego przekonywali, że odpowiedzialność za „krwawą łaźnię” spada na demokratów i spiskowców, którzy zasiali ziarno rewolucji. Demokraci z kolei winą obarczali szlachtę, często w okrutny sposób egzekwującą pańszczyznę, rozpijającą chłopów, traktującą ich jak „żywy inwentarz" ${ }^{20}$.

${ }^{16}$ Rok 1846 w Galicji..., s. 254-256, 258. W Bibliotece Naukowej PAU i PAN, rkps 1645, znajduje się "Spis osób zamordowanych przez chłopów w roku 1846, o ile dało się zebrać, sporządzony przez Stanisława Larysza Niedzielskiego ze Śledziejowic, 25 X 1893. Obejmuje 403 nazwiska w kolejności alfabetycznej - właścicieli ziemskich, administratorów, dzierżawców, urzędników i innych. Rękopis opatrzony jest mottem: „Przebacz im Panie, bo nie wiedzą, co czynią”.

${ }_{17}$ S. Kieniewicz, Ruch chłopski..., s. 259-260.

18 K. Ślusarek, Drobna szlachta w Galicji 1772-1848. Kraków 1994, s. 32-33, 36, 40.

19 S. Schnür-Pepłowski, Z przeszłości..., s. 456.

${ }^{20}$ F. Ziejka, Misjonarz..., s. 66. 
Zgodnie z późniejszymi, już po rabacji wygłaszanymi kazaniami proboszczów i kaznodziei misyjnych czy umoralniającymi gawędami dla ludu, nieurodzaj i głód, tyfus i cholera, które nadeszły, to dopust Boży, kara za rabacyjne grzechy $^{21}$. Na marginesie wydarzeń z lutego i marca 1846 roku warto zauważyć, że wiele rodzin chłopskich stanęło po stronie ofiar, dając lokalnej szlachcie i służbie dworskiej schronienie bądź umożliwiając ucieczkę, co spotkało się z wieloletnią wdzięcznością uratowanych. Co ciekawe, część chłopstwa, która splamiła się mordami, grabieniem dworów i plebanii, z czasem otoczona została wzgardą środowiska ${ }^{22}$.

Naocznym świadkiem rabacji galicyjskiej był ks. Jan Popławski, ówczesny proboszcz w Niegowici, wsi w powiecie wielickim, pomiędzy Marszowicami a Krakuszowicami. W XIX wieku na północnym krańcu wsi stał drewniany wówczas kościół pw. Wniebowzięcia Najświętszej Marii Panny i plebania, a na południu obszerny dwór z zabudowaniami. Parafia niegowicka należy do najdawniejszych, gdyż została utworzona w 1049 roku $^{23}$.

Ksiądz Jan Popławski urodził się w 1800 roku w Niedźwiedziu jako syn Andrzeja i Brygidy z Wybranowskich. Szkołę powszechną ukończył w Myślenicach, a gimnazjum w Podolińcu. Filozofię studiował we Lwowie i w Przemyślu, a teologię we Lwowie. W tym mieście, 8 września 1825 roku przyjął święcenia kapłańskie z rąk abp. Andrzeja Ankwicza. Rozpoczął pracę jako wikary w Gródku, od 1 grudnia 1826 roku był administratorem w Zborowicach, od 1 lutego 1827 roku w Staszówce, od marca roku 1827 w Siedliskach-Bogusz. Na probostwo w Cmolasie koło Kolbuszowej został instytuowany 4 kwietnia 1930 roku. Z powodów politycznych, jako podejrzany, został usunięty z probostwa 20 marca 1836 roku. Odwołał się do cesarza i sprawę wygrał. Nie mógł jednak pozostać na probostwie w Cmolasie. Chwilowo, od 1 kwietnia 1839 roku rezydował w Grybowie. 20 sierpnia 1839 roku został instytuowany na probostwo w Niegowici. Wyremontował kościół i upiększył go m.in. nową polichromią. Wybudował nowe budynki gospodarcze, dom dla ubogich i chorych, odnowił zniszczoną szkołę. W 1875 roku

${ }^{21}$ K. Poklewska, Krew na śniegu. Rzecz o rabacji galicyjskiej w literaturze polskiej. „Łódzkie Towarzystwo Naukowe. Prace Wydziału I - Językoznawstwo, nauki o literaturze i filozofii”, nr 86, Wrocław 1986, s. 73 .

${ }_{22}$ W. Hop, Jakub Szela..., s. 18. Przykłady włościańskiej lojalności wobec dworu podaje S. Kieniewicz, Ruch chłopski..., s. 209.

${ }_{23}$ [M. Maciszewski] Mac, Niegowieć. W: Słownik geograficzny Królestwa Polskiego i innych krajów słowiańskich. T. 7. Pod red. B. Chlebowskiego, W. Walewskiego, F. Sulimierskiego. Warszawa 1886 , s. 75. 
obchodził złoty jubileusz kapłaństwa, a w 1890 złoty jubileusz proboszczowania w Niegowici. Zmarł 3 kwietnia 1892 roku. Pochowany został 5 kwietnia na niegowickim cmentarzu, a jego pogrzeb odprawił kard. Albin Dunajewski ${ }^{24}$.

Pamiętnik ks. Popławskiego obejmuje okres od 22 do 24 lutego 1846 roku, czyli tylko 3 dni. Wszystko wskazuje na to, że planował kontynuować swoje wspomnienia, gdyż widzimy wpisaną jego ręką datę 25 lutego - Popielec. Wspomnienia napisał dla rodziny w 1857 roku, czyli 11 lat po krwawych wydarzeniach. Wydaje się jednak, że te burzliwe zajścia dobrze wryły się w pamięć proboszcza w Niegowici, którego życie do tej pory, jak można domniemywać, upływało spokojnie wśród codziennych obowiązków. Relacja wydarzeń z rabacji galicyjskiej jest bardzo szczegółowa, opisana z wielkim ładunkiem emocjonalnym. Ksiądz Popławski nie ukrywał swego przerażenia i zdumienia z postawy okolicznych włościan. Skoncentrował się na wydarzeniach mających miejsce w niegowickim kościele i plebanii, ale też przytoczył fakty zachodzące w najbliższej okolicy, o jakich mu donoszono. Autor wspomnień wdzięczny jest Opatrzności za zachowanie go przy życiu, jednak wskutek tego, iż jego relacja urywa się, nie znamy dalszych losów brata Sebastiana Popławskiego pojmanego przez chłopów w celu odwiezienia do cyrkułu. Pamiętnik ks. Popławskiego jest cenny jako relacja naocznego świadka rzezi galicyjskiej i przyczynek do historii tego burzliwego i tragicznego czasu w naszej historii.

Rękopis edytowany poniżej liczy 40 stron, a ostatnia $\mathrm{z}$ nich jest niezapisana. To nieco już rozpadający się na zszyciu brulion, bez okładki, o wymiarach $22 \mathrm{x}$ $17,5 \mathrm{~cm}$. Tekst sporządzony jest, jak wszystko na to wskazuje, ręką autora pamiętnika, ks. Jana Popławskiego w 1857 roku. Na górze pierwszej strony znajduje się adnotacja napisana inną ręką: „autor ks. Popławski, proboszcz w Niegowici”,

${ }^{24}$ Archiwum Diecezjalne w Tarnowie: Autobiografia ks. Jana Popławskiego, sygn. Ab VI P/19; Teczka Personalna sygn. PP V/10, biogram A. Nowaka w: Słownik biograficzny kapłanów diecezji tarnowskiej 1786-1985. T. 3. Tarnów 2001, s. 326. Ponadto: „Wykaz księży parafii Niegowić od 1717 r.”, s. 11 (rkps), przechowywany przy kościele w Niegowici. Tam podano 1 kwietnia jako datę śmierci ks. Popławskiego. Za udzielone informacje dziękuję ks. proboszczowi w Niegowici ks. Pawłowi Sukiennikowi oraz ks. Stanisławowi Tokarskiemu z Archiwum Diecezjalnego w Tarnowie. 
a kolejną ręką notatka ołówkiem wzdłuż tekstu, mocno już wyblakła: „dar inspektora Seweryna Udzieli 18/3 1925”. Rękopis pamiętnika sporządzony został czarnym atramentem, czytelnym charakterem pisma, z występującymi nielicznymi skreśleniami, które są spowodowane zastąpieniem danego sformułowania czy słowa innym, stosowniejszym w zamyśle autora.

Przy opracowywaniu pamiętnika wzięto pod uwagę Instrukcję wydawnicza dla źródeł historycznych od XVI do XIX wieku Kazimierza Lepszego (Wrocław 1953). Ingerencje edytorskie w tekst są nieznaczne - polszczyzna i pisownia autora w nieznacznym tylko stopniu odbiega od współczesnego języka. W oryginalnym brzmieniu zachowano występujące właściwości fonetyczne, stylistyczne i gramatyczne tekstu. Znacznej modernizacji uległa tylko interpunkcja. W nawiasach kwadratowych podano uzupełnienia edytora. W przypisach rzeczowych wyjaśniono terminy mało znane oraz miejscowości czy nazwiska.

Jak już wspomniano, pamiętnik ks. Jana Popławskiego stanowi oryginał, spisany jest bowiem jego ręką. Jednakże w Muzeum Etnograficznym w Krakowie, w Dziale Dokumentacji Kontekstów Kulturowych (Archiwum MEK), znajduje się odpis tego tekstu, sporządzony zapewne na polecenie Seweryna Udzieli, znajdujący się w jego spuściźnie. Pamiętnik ks. Popławskiego znajduje się wśród odpisów innych relacji z czasów rabacji chłopskiej z 1846 roku, w tomie zatytułowanym „Rok 1846 - wyciągi z kronik kościelnych oraz wspomnienia właścicieli ziemskich", liczącym 94 karty. Poszczególne zeszyty zawierają: relację ks. Stanisława Osuchowskiego proboszcza w Bieżanowie, anonimowe opisy wydarzeń w Biskupicach, Dziekanowicach i Gdowie, relację ks. Józefa Dzielskiego proboszcza z Łazan, opisy wydarzeń autorstwa ks. Jan Komperdy - proboszcza z Podstolic, ks. Jana Michalskiego z Raciechowic, Anny z Pilchowskich Klimatowej ze Stojałowic, ks. Andrzeja Zembrzyckiego z Wiśniowej i Gałuszowic ${ }^{25}$.

Należy nadmienić, że pamiętnik ks. Popławskiego publikowany był wśród innych relacji z czasów rabacji chłopskiej, a edytorzy korzystali z odpisu przechowywanego w Muzeum Etnograficznym w Krakowie. Tekst ten jednak pozbawiony jest wstępu i przypisów niezbędnych dla edycji ${ }^{26}$.

${ }_{25}$ Muzeum Etnograficzne w Krakowie, Dział Dokumentacji Kontekstów Kulturowych (Archiwum MEK), nr inw. I/380/rkp. Odpis pamiętnika ks. Jana Popławskiego na kartach 44-61.

${ }^{26}$ Rok 1846 w Galicji..., s. 259-265. 


\section{PAMIĘTNIK KS. JANA POPŁAWSKIEGO, PROBOSZCZA Z NIEGOWICI DOTYCZACCY RABACJI CHŁOPSKIEJ 1846 R.}

Biblioteka Naukowa PAU i PAN w Krakowie, rkps 1938, ss. 40. Oryginał.

\section{[s. 1] Pamiętnik z roku 1846go skreślony dla członków familii swojej w roku 1857}

Napisz to dla pamięci w księgi

(Exodus 17,14)

Tak wspomniany został ów wielki wódz ludu izraelskiego, aby przekazał potomności łaski Najwyższego. Tym nakazem i ja, lubo niegodny sługa Boży, upomnianym być się poczuwam, aby choć w słabych wyrazach - ale wyrazach rzetelnego serca napisać to, co w żywem przypomnieniu sobie na rok [1] $846 \mathrm{wy}-$ obraźni mojej, jako obecnie mi się przedstawia. Rozbierając toczące się wypadki w owym roku [1]846, cud Boży widzę nad sobą, że żyję, że nie uległem ciosom śmiertelnym.

[s. 2] Rok ten bieżący [1]857, co do kalendarza przypada ten sam, co rok [1]846 był, gdyż równie 25 lutego tego roku Popielec i równie [2] $5 \mathrm{w}$ roku 1846 przypadał. Wypadki więc 22 lutego zacząwszy, w następnych dniach toczące się, żywo mi się przed oczy przesuwają.

\section{Dzień 22 lutego}

Dzień ów był niedzielą quinquagesimae ${ }^{27}$ - zapustna niedziela - w rannych godzinach panowie Romerowie, jako to pan Ludwik, pan Michał - bracia rodzeni (pan Aleksander został był z matką swą panią Romerową w Krakowie), opuszczają Krakuszowice ${ }^{28}$, odwiedzają mię w przejeździe do Jodłownika, pytają się mię i niejako rady ode mnie zasięgają, czy li byliby bezpiecz[n]emi od napa-

${ }_{27}$ Quinquagesimae - Quinquagesima Dominica - niedziela przed Popielcem.

${ }_{28}$ Krakuszowice - wieś w pow. wielickim, należąca do parafii w Niegowici, $10 \mathrm{~km}$ od Bochni, $12 \mathrm{~km}$ Od Wieliczki. 
ści ludu w Krakuszowicach i w jakiejsi obawie, udają się w bezpieczne miejsce do Jodłownika ${ }^{29}$ [do] swego brata, do pana Konstantego. Zagadniony owem zapytaniem, zdumiałem się, nie pojmując [s. 3], co było znaczyło. A że się spieszyli, przejęci jakąś trwogą, czasu nie miałem po temu, ile że i do kościoła mi iść trzeba było, wybadywać z nich przyczynę trwogi, którą jak widać było z ich umysłowego wzruszenia, przejęci byli. Tem swoim zapytaniem, mię oni zaambarasowali tak, że aktualnie nie wiedziałem, jaką im mam dać odpowiedź. Gdy jednak w owej chwili zreflektowałem się, iż często bardzo trafiały się mi przypadki, gdzie przy zaopatrywaniu chorych Sakramentami, a szczególnie we wsi Wiatowicach ${ }^{30}$ (do ich majętności należącej), przy zwykłych naukach do obecnej młodzieży, starzy chłopi przeciw pańszczyźnie tak zwanej jakieś oburzenie okazywali, [s. 4] których naprowadzać na drogę prawej zrozumiałości mi przynależało, przedstawiając im, iż obowiązek odrabiania dni pańszczyźnianych do dworu jest to obowiązek od dziada pradziada przywiązany do gruntu, którego użytek posiadają, bo grunt sam jest istotnie do dworu należący. Tak im i podobnie stan rzeczy przedstawiając, naukę starszym podawałem, aby powinności owe sumiennie odrabiali, jako czysty dług na gruncie ziemi ciążący. Jednak, gdy z twarzy ich wyczytać można było, że nie zawsze im do smaku ta nauka przypadała. Kilka razy [s. 5] sam nad ich upornem sercem zastanawiałem się.

Zaambarasowany, jak rzekłem, tych panów zapytaniem, a tych ludzi niechętność na uwagę sobie przyprowadzając - obrałem drogę dla odpowiedzi pewniejszą, to jest rzekłem im: Moi panowie! To wiem, że ludzie za Rabą ${ }^{31}$ (i Jodłownik wieś za rzeką Rabą leży), daleko przychylniejsi ku swym panom są, jak tu, tu lud jest od kogoś podburzany, tu lud ku dworom jest niechętny, to wiem, więcej nie wiem. Odebrawszy oni ode mnie to w odpowiedzi, czem prędzej pożegnali się ze mną i odjechali, udając się do pana Konstantego, swego brata, do Jodłownika.

29 Jodłownik - własność Konstantego (1817-1896) i Marii (Marianny) z Kirchnerów (18231899) Romerów, dwór obrabowany podczas rabacji; opis wydarzeń zob. S. Dembicki, Rok 1846. Kronika dworów szlacheckich zebrana na pięćdziesięcioletniq rocznicę smutnych wypadków lutego. Jasło 1896, s. 176-179. Podczas rabunku kobiety przetrząsając pościel dziecięcą w poszukiwaniu ukrytych kosztowności wyrzuciły na podłogę niemowlę, którym był Gustaw (1846-1093), późniejszy prawnik, bankowiec i poseł na sejm galicyjski. Zob. L. Żuławski, Oblężenie Limanowy..., s. 123.

30 Wiatowice - wieś w pow. wielickim należąca do parafii w Niegowici, ok. 7 km od Gdowa. Od wschodu graniczy z Krakuszowicami, od południa z Liplasem.

${ }^{31}$ Raba - prawy dopływ Wisły. 
[s. 6] Po odjeździe ich, sam siebie w duchu pytałem, co to znaczy owa tych panów jakaś obawa? Skąd to? Gdy te myśli mi głowę zakłopociły, koło południa słyszę od ludzi do kościoła na nabożeństwo jako w niedzielę idących, iż wojska porozstawiały warty po drogach i kogoś się obawiają. Tu mię znowu na nowo to zastanowiło. I tak nadszedł wieczór. Wieczór że poprzedni dzień, w sobotę, było św. Eleonory, z tego powodu uczta w Gdowie ${ }^{32}$ u państwa Fihauserów (żonie Henryka, pana Fihausera, na imię jest Eleonora). Braterstwo moi, Sebastyjan i Maryjanna Popławscy tam zaproszeni pojechali. Około 9 godziny wieczór, państwo Fihauserowie przysełają po mnie, a to i w tym celu, aby porozstawiane warty [s. 7] po drogach, braterstwo moich z Gdowa powracających nie atakowały, ale wolno wszędzie aż tu, do Niegowici przepuszczały.

Tam w Gdowie dopiero posłyszałem o wybuchłych rozruchach w Krakowie, a jak mówili, także i w Tarnowie. Wszystkiego tego pojąć nie mogłem. Zabawa u państwa Fihauserów, lubo wszystko było po obywatelsku przyrządzone, jednak czegoś nie była ochocza, jakaś trwoga mimowolnie prawie każdego owładała.

Powróciliśmy do domu około dwunastej, ale ze ściśnionem sercem, jak gdyby w przeczuciu okropnych nastąpić mających wypadków.

\section{[s. 8] Dzień 23 lutego}

W całym tym dniu nic nowego więcej słychać nie było, jak to, że warty wszędzie jeszcze mocniej porozstawiane, na kogoś czekały, same nie wiedząc na kogo. Wieczór dają mi znać, iż kilku z chłopskiej młodzieży, lampartów ${ }^{33}$, umawiali się iść tu na plebanią i okna potłuc, ale chałupnik ${ }^{34}$ plebański Wojciech Stopa rozperswadował im, aby tego nie czynili, bo (rzekł on) gromada i tak musiałaby okna nowe posprawiać.

\section{Dzień 24 lutego}

Dzień ów tu był w całem znaczeniu okropny. Rano o w pół do ósmej, ubieram się do mszy św., organista Szymon Orzechowski, ubierający mię,

32 Gdów - miasteczko w pow. wielickim. Odnotowano, że w Gdowie zamordowani zostali Gross z Krzyworzeki i Stanisław Trzcienicki, czternastoletni chłopiec. Zob. S. Dembicki, Rok 1846 w Galicji..., s. 417.

${ }^{33}$ Lampart - łobuz, nicpoń, hulaka.

${ }^{34}$ Chałupnik - bezrolny chłop, posiadający tylko chałupę z obejściem. 
mówi mi w zachrystyji, ale mówi ze zadyszałymi piersiami, [s. 9] mówi straszną wiadomość: Panie Dobrodzieju! W Grotkowicach ${ }^{35}$ pan Żeliński ${ }^{36}$ zabity! Zadrżałem na to doniesienie! I wszyscy co w owej chwili stali w zakrystyji przerażeni zostali (okropną tą tragiczną scenę, osobno na końcu w dodatku opiszę). Pytam się organistę Szymona Orzechowskiego, skąd to wie? Co za przyczyna tego zabójstwa? Ludzie mówią wszyscy (odpowiada mi), co od Krakuszowic i Cichawy ${ }^{37}$ tu do kościoła przyszli (mam tu namienić, iż poniedziałek i wtorek przed Popielcem, jest tu 40-godzinne nabożeństwo) - wszyscy o tem mówią i mówią, że go chłopy zabili, czyli raczej zamordowali. [s. 10] Chłopy? - zadziwiłem się. Wszak ten pan dla chłopów dobrocią swoją był wylany. Dalej pomyślałem sobie: ten pan, dla chłopów, dla ludzi powodzią Wisły unieszczęśliwionych, podpisy zbierał tu w okolicy u obywateli w celu otrzymania wsparcia w ziarnie, w groszu itp. darów, aby nad owymi biednemi czyn miłosierdzia wykonać. Ten pan w tym celu objeżdżając obywateli, każdego zagrzewał tą wzniosłą myślą, iż największą wspaniałomyślnością jest nieszczęśliwym iść na ratunek. Ach, mój Boże! I ten pan miasto wdzięczności miał ponieść śmierć [s. 11] i morderstwo?! Tą myślą wzruszony, kończyłem ubieranie się do mszy św. - bezkrwawej ofiary Tego, który i za owych Krew Swoją dał przelać, którzy Go krzyżowali! Ach czcigodny obywatelu! Dalej myśl mimowolnie przesuwała mi się: pokój szanownym zwłokom twoim. Ty stałeś się odwzorem Zbawiciela twego!

Gdy już miałem ze mszą św. wychodzić, wchodzi do zakrystyji cooperator ${ }^{38}$ ks. Bilecki, powróciwszy od chorego z Pierzchowa ${ }^{39}$ i mówi znowu smutną wia-

35 Grotkowice - właść. Grodkowice - wieś w pow. bocheńskim, nad Rabą. Odnotowano, że w Grodkowicach oprócz jego dziedzica zostali zamordowani: nauczyciel Promer i Stanisław Stański, dziedzic Chomranic. Zob. S. Dembiński, Rok 1846 ..., s. 417.

${ }^{36}$ Marcyjan Żeleński. Z relacji Jana Szczepanika „Rabacja. Bitwa pod Gdowem. Czasy pańszczyźniane”: „Dziedzic w Grodkowicach hardy i dumny nie chciał się władzom austriackim podporządkować. Broni - jak na te czasy - było u niego dosyć dla powstańców. Służył w wojsku w randze kapitana. W Grodkowicach zbierała się szlachta z okolicznych wsi [...]" (Rok 1846 w Galicji..., s. 358). Według innej relacji „żonę Marcyjana Żeleńskiego, która wyszła z czworgiem dzieci naprzeciw czerniawy, stratowało chłopstwo nogami na schodach dworu” (S. Schnür-Pepłowski, Z przeszłości..., s. 439-440).

37 Cichawa - wieś w pow. wielickim należąca do parafii w Niegowici, 10 km od Gdowa.

${ }_{38}$ Cooperator - pomocnik proboszcza, wikariusz.

39 Pierzchów - wieś w pow. bocheńskim na lewym brzegu Raby, 8 km od Bochni. Graniczy z Niewiarowem i Nieznanowicami. 
domość, iż słyszał we dworze $[w]$ Nieznanowicach ${ }^{40}$ dwa strzały, a ludu tam na podwórcu ogromna moc. [s. 12] To mię znowu przeraziło, tak że o mało nie zemdlałem, a lubo nie wiadomo było nam, co się tam stało, jednak trwoga ogromna ogarnęła nas. (Owa chwila, było to tam inne morderstwo, pan Kęmpiński i jego żona Stefania i jej brat Mieczysław Dębicki i służący lokaj Leo Bilecki, zabici zostali. Tę tragiczną scenę osobno w dodatku opiszę) ${ }^{41}$.

Wyszedłem ze mszą św., ale trwogą całkiem przerażony, nogi pode mną drżały. Lud na owo 40-godzinne nabożeństwo, w ów dzień, nadzwyczaj licznie się zgromadził. Tak mocno był napełniony kościół, że zdawało się, iż już ani jeden więcej człowiek pomieścić by się nie mógł. Przed rokiem pierwej towarzystwo wstrzemięźliwości ${ }^{2}$ tu zawiązane zostało i przykładnie się zaczęło utrzymywać, przeto też i lud do kościoła się licznie zgromadził. Cechowi bracia, światło brackie [s. 13] do rąk ludziom porozdawali.

Zacząłem mszę św. Skupiam myśli, natężam uwagę na teksta mszy św., silę się, aby uważnie ten wielki akt jak jest ofiara mszy św. pełnić, ale przecie drżę od trwogi. Po Credo43 jakoś w pierś zaczęło wstępować uspokojenie. Lud nabożnie śpiewa, następnie Sanctus ${ }^{44}$, a wtem niedługo słychać krzyk ode drzwi wielkich: gwałtu! Polacy idą rżnąć nas... Na ten odgłos: Polacy nas rżną! ogromny w kościele powstał krzyk, zamieszanie i powszechna trwoga. Lud tłumem garnie się ku wielkiemu ołtarzowi przez zakrystyjkę z kościoła uciekać, mnie celebrują-

${ }^{40}$ Nieznanowice - wieś w pow. wielickim, na lewym brzegu Raby, 5 km od Gdowa. Na zachód graniczy z Marszowicami.

${ }^{41}$ Ks. Jan Popławski w rzeczywistości nie opisał tej sytuacji; jego pamiętnik wydarzeń nie został doprowadzony do końca. W Nieznanowicach chłopi zamordowali: „nie tylko bowiem [Henryka] Kępińskiego, ale i żonę jego [Stefanię] ciężarną, zasłaniającą go przed cepami napastników", „Kępiński od dawna znany był w kraju z braterskiego i dobroczynnego obchodzenia się z ludem”. Ponadto zamordowany został dziedzic Mieczysław Dębicki i lokaj Leon Bilecki. Zob. S. Dembiński, Rok $1846 \ldots$, s. 56, 243-244 (opis wydarzeń). Według innej relacji trupy wówczas zamordowanych zawieziono wraz z innymi zabitymi do cyrkułu w Bochni. Zob. S. Schnür-Pepłowski, Z przeszłości..., s. 439 .

${ }_{42}$ Towarzystwo wstrzemięźliwości - masowy ruch mający na celu uchronienie ludności włościańskiej od pijaństwa, a także ożywienie religijności i moralności poprzez urządzanie dla członków nabożeństw z kazaniami. Towarzystwa wstrzemięźliwości prowadziły ożywioną działalność zwłaszcza po rabacji, w której uczestniczyło wielu chłopów pod wpływem alkoholu. Zob. więcej: C. Czechowska, Towarzystwa wstrzemięźliwości w diecezji tarnowskiej za rządów biskupa J.G. Wojtarowicza (1844-1850). Lublin 1981.

43 Credo - wyznanie wiary odmawiane w czasie Mszy św. w niedziele i uroczystości.

${ }_{44}$ Sanctus - podczas modlitwy eucharystycznej aklamacja "Sanctus, sanctus, sanctus” (święty...). 
cego do ołtarza aż przycisnęli. W nawie kościoła lud trzymający w ręce gorejące świece, w tumulcie [s. 14] gruchocze takowe, inni biorą się do jakiegoś bronienia się, biorą lichtarze z pobocznych ołtarzy, inni sztangi z chorągwi, aby przeciw (jakimś) Polakom odpór dawać. Gdy taki tumult trwa około kwadransa godziny, pan Szybalski (Michał) ${ }^{45} \mathrm{z}$ Niewiarowa ${ }^{46}$ będący na nabożeństwie obecny (była także i pani Ciepielewska ${ }^{47}$ dziedziczna pani Niegowici i Marszowic ${ }^{48}$, kolatorka ${ }^{49}$ kościoła wraz z panną Mirecką przybocznią swoją towarzyszką), staje aż na ławkach kolatorskich i woła: uspokójcie się ludzie, uspokójcie się, dajcie kapłanowi ofiarę mszy św. odprawiać, bo ktoś tylko bajkę wznowił. Potem [s. 15] a raczej równocześnie, do sług kościoła należący Augustyn Chmielek, co światło brackie utrzymywał, od ołtarza pchając się ku środku kościoła, oboma rękami z góry na dół je znosząc, skazuje i nakazuje niejako ludowi, aby się uspokoił. I nastąpiło przecie uspokojenie.

Tu mi wypada zboczyć z opowiadania faktu, na nadmienienie przyczyny takiego w kościele hałasu i trwogi. Parę tygodniami przed 22 lutego krążyła tu wieść między ludem, a zwłaszcza po karczmach, iż ze dworów panowie ze swojemu lokajami będą w nocy wycieczkę czynić na wsie [s. 16] i ludzi prostych, wieśniaków, w pień rżnąć, znać [sic] aby ich grunta w posiadanie pobrać. Na takie wieści śmialiśmy się wszyscy i mniemaliśmy, iż jakiś ludwisarz, co dzwony przelewa, taką bajkę ze zabobonności puścił, aby się mu dzwony udarzyły. Jednak ta bajka, na umyśle ludu, tak okrutnie fałszywe wrażenie uczyniła, że powzięli to mniemanie, iż będą w pień wyrzynani. Nic dziwnego więc, iż gdy jakiś niegodziwy frant na koniu przybiegł ku kościołowi, rzekł do żebralnych babek, co w babińcu tuż przy kościele siedziały: Polacy idą rżnąć nas! - Te zaraz ludziom [s. 17] dopowiedziały i stąd ta ogromna trwoga, hałas, krzyk w kościele powstał. Mówią niektórzy, iż ten, co przypadł na koniu, był dał znać, iż chłopi zabijają Kęmpińskich w Nieznanowicach i że babki żebralne źle go zrozumiały i podług swego uprzedzenia wieść o Polakach dalej ludziom dopowiedziały. Że zaś owe babki pomylić się nie musiały, dowodem jest inna okoliczność, okoliczność to ta, iż równie w ów czas w Bochni ktoś także

45 Dziedzic Michał Szybalski został zamordowany podczas rabacji. Zob. Rok 1846..., s. 418.

${ }^{46}$ Niewiarów - wieś w pow. wielickim, nad Rabą. Na zachód graniczy z Niegowicią.

47 Anna Ciepielewska.

${ }_{48}$ Marszowice - wieś w pow. bocheńskim na lewym brzegu Raby, między Bochnią a Gdowem. Należała do parafii w Niegowici.

49 Kolator - fundator kościoła w swoim majątku lub wyposażający go, z prawem do przedstawiania kandydatów na proboszcza. W kościele miał swoją ławkę. 
do kościoła przypadł i rzekł: Polacy idą rżnąć nas, ale ludzie tam mądrzejsi [s. 18] temu przecie nie dali wiary.

Teraz wracam się do kościoła w ową chwilę, gdzie nastąpiło ludu uspokojenie. Skończywszy mszę św., odśpiewawszy suplikacyje $e^{50}$, uczułem się być obowiązanym iść na ambonę i lud z błędu wyprowadzić. W nauce, jaką 40-godzinne nabożeństwo wymaga, przytoczyłem naukę, iż Bóg jest Ojcem wszystkich ludzi, my między sobą, czy Niemcy, czy Węgry, czy Polacy jesteśmy między sobą bracia, ta jest wola Boga, abyśmy się wszyscy obserwowali, miłowali jeden drugiego, w nieszczęściu ratowali, boć przykazanie miłości Boga i miłości bliźniego [s. 19] jest fundamentem wszystkich innych przykazań. Kto więc to pierwszy wznowił, iż Polacy rżną nas - powiedział szatańską bajkę, a wyście ludzie tej bajce uwierzywszy, wyrządziliście zniewagę chwale Pana Boga! Gdy oto tyle świec poświęconych, gromnic pogruchotanych zostało! Więc ludzie, jak możecie przeprosić Majestat Boski, gdy zejdę z ambony, a padnę krzyżem na środku kościoła, padnijcie wy krzyżem za mną, a leżąc krzyżem poodmawiajmy w duchu pokuty po pięć pacierzy. I tak uczyniliśmy, a lud z odurzenia oswobodzony (dzięki Bogu), z kościoła do domów popowracał.

[s. 20] Lud, co w kościele był, powracał do domów oswobodzony z odurzenia, ale wszystek wszystek całej parafii lud, z 4 ooo dusz przeszło składającej się, w kościele nie był, inni wszyscy tak prędko owo tak niegodziwe uprzedzenie poporzucać nie mogli, a w tym błędzie uplatani, występków przeciw miłości bliźniego podopuszczali się.

Z kościoła, gdy wszedłem do mego mieszkania, słyszę doniesienie, iż chłopi ze wsiów kameralnych Państwa Niepołomskiego ${ }^{51}$, jako to z Książnic ${ }^{52}$, Łęczkowic $^{53}$, z Kłaja ${ }^{54}$, obstąpili dwór w Niewiarowie i tam wszystko co było potłukli, okna, drzwi pogruchotali, nawet posadzkę powywalali. Ze spiżarni masło, słoninę, mąkę, [s. 21] sery i naczynia kuchenne miedziane i żelazne pozabierali. Suknie męskie i garderobę damską, wszystko a wszystko, między sobą poroz-

5o Suplikacja - religijna pieśń kościelna Święty Boże.

${ }_{51}$ Wsie Państwa Niepołomskiego - po I rozbiorze Polski w 1772 roku ekonomia niepołomicka (stołowe dobra królewskie) została zagarnięta przez Austrię. Już w styczniu 1773 roku zostało utworzone rządowe dominium niepołomickie, które przetrwało do końca I wojny światowej. „Państwo niepołomskie” to dobra kameralne, czyli rządowe.

${ }^{52}$ Książnice - wówczas Małe i Wielkie, wsie w pow. bocheńskim, po obu stronach Raby.

53 Łęczkowice - Łężkowice, Łęszkowice - wieś w pow. bocheńskim na lewym brzegu Raby. Na południe graniczy z Książnicami.

${ }^{54}$ Kłaj - wieś na lewym brzegu Raby, na skraju puszczy niepołomickiej. 
szarpali. Pana Szybalskiego (Michała) właściciela owej wioski związali, kijami i cepami bez litości ubili, a tak związanego do Bochni powieźli. Jego żonę, panią z baronów Gostkowskich ze wszystkim obrabowali, ledwie w lichym odzieniu ją zostawili przy życiu, tak dalece, że ani chustki do zarzucenia na się jej nie zostawili.

Po dopełnionym rabunku w Niewiarowie mieli zamiar napaść na plebanią niegowicką, to jest na mnie, [s. 22] ale że spostrzegli patrząc przez łąki ku dworowi niegowickiemu, iż od tego dworu chłopi inni powracają, już na plebanią nie poszli, ale czem prędzej polecieli przez łąki na dwór niegowicki, na dziedziczną panią, panią Ciepielowską. Namieniłem dopiero teraz, że inni chłopi od tego dworu powracali, byli to chłopi ze wsi Wiatowic, tutejszej parafii, którzy po nabożeństwie z kościoła wyszedłszy, razem kilkadziesiąt zebranych, poszli do pani Ciepielowskiej. Kilku ich weszli do dworu z odkrytą przyzwoicie głową (reszta ich na podwórcu się zostali) i w te słowa wyrazili się: Daruje pani, że tu [s. 23] przybyliśmy, mamy rozkaz szukać broni, fuzyj, pistoletów, szabli itp., a że wiemy, że u pani tego wszystkiego nie ma, więc przyszliśmy tylko, aby rozkaz wypełnić i kłaniamy się pani i niech nam pani daruje, żeśmy może zaambarasowali. Tak więc uczyniwszy pokłon, odeszli (to wszystko z ust pani Ciepielowskiej słyszałem).

Wtem gdy ci odeszli, owi kameralraki wpadają na dziedziniec i jak wściekłe furie od razu siekierami, toporami we drzwi uderzają. Z największą wściekłością krzesła, kanapy, lustra, obrazy tłuką, ze szpiżarni wszystko, z piwnic wszystko, z kredensu wszystko, łyżki, sztućce, srebro wszystko. [s. 24] Rozszarpują garderobę, bieliznę tak stołową jako i do ubrania, chustki wszystkie, mantyle55, futra, zgoła wszystko a wszystko pomiędzy siebie rozdzierają i kijami nad panią Ciepielowską wywijają. Szczęściem, że parę z wiatowickich chłopów, co na samym ostatku się z powracających pozostali, między tych kameralraków się wmieszali, i ci, a mianowicie Zawacki Wojciech zasłonił od już, już paść mającego kija na panią Ciepielowską. Niezawodnie ten jeden cios byłby ją był trupem położył.

Gdy ów dwór rabowali, mój cooperator ks. Bilecki ${ }^{56}$, widząc tam, co się działo, wpada tu na plebanią i woła [s. 25] do moich braterstwa: Panie, uciekajcie, bo was pozabijają! W pole nie sposób, bo ostre powietrze było, a zresztą gdzież? Oto przynajmniej do kościoła się schrońcie! Tak więc: bratowa moja Maryjanna Popławska ze swemi dwoma córeczkami Anną i Konstancyją do kościoła się

55 Mantyla - rodzaj peleryny, zarzutka kobieca bez rękawów.

${ }_{56}$ Ks. Iwo Bilecki - przybył do parafii w Niegowici w 1845 roku, odszedł do parafii w Czchowie W 1853 roku. 
schroniły, zaś mój brat Sebastyjan Popławski schronił się nad oranżeryję, wziąwszy siekierę ze sobą, aby się bronić przeciw napaści. I dalej mówi ksiądz Bilecki do mnie: I ksiądz proboszcz nie jest bezpieczny, bo tam słychać, że się i na księdza proboszcza usadzili, zresztą oto [s. 26] jednem słowem powiedzieć, lud to tam wściekły jest, wszyscy, co są surdutowi, a szczególnie tych, co są szlacheckiego rodu, wszystkich chcą śmiercią położyć. To mi oznajmiwszy, poszedł do kościoła, aby tam zamknąć te trzy osoby i opuścił mię. A lubo on był 2 mile stąd, z Cerekwi ${ }^{57}$ rodem, ojca wieśniaka mając, a z tego względu popularność między prostym ludem posiadając, jednak on o sobie już zwątpił, bo się mi w ten dzień na oczy nie pokazał, kiedy potrzeba było około mnie ratunku. Oznajmiwszy mi zapęd owych rozhukanych ludzi, samego mię w mieszkaniu swoim zostawił.

Widząc niejako [s. 27] mi już zapowiedzianą śmierć, oto uczyniłem akt skruchy, odmówiłem antyfonę: „Pod Twoją obronę uciekamy się, Święta Boża Rodzicielko", etc. i uczyniłem sobie ślub, iż dopóki tu plebanem będę, zawsze o to dbać chcę, aby w każdy piątek msza św. śpiewana przed ołtarzem Najsłodszego Serca Pana Jezusa odprawianą była. A w tej rezygnacyji oczekuję spełnienia woli Najwyższego nade mną. Będąc ubrany w sutannę, wziąłem i komżę na siebie.

Około 12 godziny w południe nadciąga hałastra chłopów, tu, na plebanią.

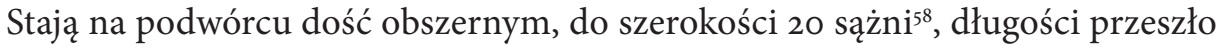
30 sążni mającym, a tę przestrzeń napełnili prawie całą. Uzbrojeni w kije, widły od siana, [s. 28] niektórzy mieli i siekiery. Wyszedłem do nich przed ganek, widzę ich tak uzbrojonych, a do tego pobłoconych, na twarzy posmolonych, wielu ich pijanych, mało, bardzo mało trzeźwych. A lubo ich tak wielu było, nie byli to atoli wszyscy ci, co z powrotu ze dwora nadciągali, bo znaczny ich oddział obładowany łupem dopełnionego rabunku we dworze pani Ciepielowskiej kolatorki oddzielił się i do domów swych poszedł, reszta ich tu na podwórcu stanęła.

Jak namieniłem, wyszedłem przeciw nich na ganek i mówię tak do nich: Witajcież chrześcijanie! Czegoż chcecie? [s. 29] Mamy rozkaz - odpowiadają - szukać broni, fuzyj, strzelb różnych i po to tu przyszliśmy. Gdy to przed gankiem mówią, wielu z nich pozdejmowało czapki i kapelusze z głowy, ale się jako pijani zataczali. Mając ja przy boku moim ku jakiej takiej obronie mojej uczciwego włościanina z Pierzchowa imieniem Augustyna Chmielka - Boże! Przyjmij go do chwały Twojej! - należącego do sług kościelnych, owego to, co światło brackie utrzymywał. Mówię dalej do nich: kiedy macie taki rozkaz, to dobrze,

57 Cerekiew - wieś w pow. bocheńskim niedaleko Uścia Solnego.

${ }^{8}$ Sążeń - dawna miara długości równa ok. $190 \mathrm{~cm}$. Sążeń $=35$ łokci $=6$ stóp. 
ale nadaremnie u mnie rewizyje czynić macie, bo przecież to dobrze wiecie, [s. 30] że ja nigdy nie poluję, nie strzelam, więc i żadnej strzelby nie mam. Ale kiedy taki rozkaz mamy - mówią do mnie - abyśmy rewidowali, to musimy to czynić. Na to im odpowiadam: Kiedy chcecie koniecznie to czynić, to czyńcież, tylko was obliguję, aby z was tylko dwóch weszło do pomieszkania, abyście mi też posadzki nie powalali i inni aby psoty jakiej nie powyrządzali. Dobrze, dobrze - wtem kłaniają się mi i ręce mi całują. Ale zamiast dwóch wpakowało się ich czterech, piąty z niemi był ów uczciwy a bogobojny Augustyn Chmielek.

Wtem, jak się ci czterech do sieni wpakowali, ze środka owej hałastry, przepycha się dwóch ku gankowi, [s. 31] innych dwóch ku drugim drzwiom od kuchni na podwórzec otwartym, zakładają na krzyż kije swoje we drzwiach i nie dopuszczają innych mających ochotę pchać się drzwiami do pomieszkania. Rzecz dziwna i warta zastanowienia! Między owymi, co założywszy swe kije na krzyż we drzwiach stanęli i nie dopuścili innych do pokojów, poznałem dwóch z mej parafii znanych, jawnych złodziei, to jest Pawła Matuszczyka inaczej Zbójnickiem zwanego z Niegowici i brata jego Jana Matuszczyka z Cichawy. Innych dwóch nie znałem. I ci czterech dali odpór hałastrze, że do pomieszkania nie wcisnęła się, prócz tych, co rewizyję [s. 32] uskuteczniać przedsięwzięli. Mnie zostawili w moim pokoju, a uczciwy Augustyn Chmielek tych rewizorów oprowadzał.

Komór i szaf u braterstwa mego nie tknęli, ja im moje szafy pootwierał, popatrzyli i nic nie ruszyli (zginęło mi wprawdzie 16 [cwancyngierów ${ }^{59}$ - odczyt skrótu niepewny E.D.], które miałem nagotowane, aby takowe ubogim [w] szpitalu porozdzielać; wielkie prawdopodobieństwo, że któryś z tych czterech rękę po takowe sięgnął). Poszli potem do piwnicy, tam szkodę wyrządzili, bo parę butelek osobliwszego wina, ile że stare, przeszło 50 lat mające, wypróżnili, a na lepszy przysmaczek wypili i butelkę szwarcu ${ }^{60}$ do butów przygotowanego.

[s. 33] Tak więc swe urzędowanie odprawiwszy, razem z hurmą z podwórca za bramę odeszli. I te dzikie tygrysy, na ów czas okazały się cichemi barankami... Wtem za bramą odezwały się głosy: A cóż to, darmo tu przyszliśmy? A wróćwa się, weźmy tego siwego pana (to jest mego rodzonego brata Sebastyjana, był już bowiem siwemi włosami pokryty). I wrócili się z hałasem wielkim.

$\mathrm{Na}$ tę nową scenę uczciwy Augustyn Chmielek i ktoś z owej bandy (ani jemu, ani mnie nie znany), przystąpił do mnie i tak do mnie mówi: Proboszczu

59 Cwancyngier - moneta austriacka równa 20 krajcarom, czyli trzeciej części złotego reńskiego.

6o Szwarc - szuwaks, czarny preparat do czyszczenia obuwia. 
dobrodzieju! Koniecznie trzeba, żeby pan okazał się im i dał się im pojmać, bo im chodzi o to, aby pieniądze za niego dostali. Ale [s. 34] moi kochani - mówię do nich - oni mego brata może będą bić! Nie - odpowiada - nie damy go bić, sumiennie ręczymy (bijąc się w piersi) - nie damy go bić. Trzeba koniecznie czem prędzej do wozu konie zaprzągnąć, aby się ich pozbyć, żeby odjechali. Na taką ich radę drżałem ze strachu i znowu ich zaklinam, żeby mu krzywdy wyrządzić nie dozwolili - oni uroczyście zaręczają i dodają i to, że ta hałastra wie, iż pan tu jest gdzieś ukryty, a szukając go, mogliby dużo spustoszenia nabroić. Na takie przedstawienia, ze strachem którego dreszczem byłem zaatakowany, wołam w głos około oranżeryjni, gdzie się mój brat schował: Proszę, błagam [s. 35] kochanego brata! Niech brat wyjdzie, oni nic złego nie wyrządzą. Słysząc głos mój, brat mój zeszedł z oranżeryjni i okazał się im, aleć gdy się we futro przebierał, bo się miało już ku wieczorowi, dwóch z owej zgrai: Kazimirczak z Pierzchowa i Jakub Feliks z Liplasa ${ }^{61}$, mocno podpici, zaczęli pięściami obkładać mego brata. Ja rzuciłem się na nich z największym rozjątrzeniem; jak jednego, tak drugiego za łeb, za kark laską, którą mi ktoś podał. I tak ich uspokoiłem, ale cóż oni robią? Oto gdy już na wóz wsiadał mój brat, wiążą mu ręce okrutnie w tył, że aż o litość wołał. A tak okrutnie skrępowanego [s. 36] powieźli do Bochni.

W drodze przy Pierzchowie dowiedzieli się poddani do plebanii należący, a mianowicie Wojciech Cecuga, iż mego brata na wozie związanego wiozą, rzucili się na nich, $\mathrm{z}$ wozu tych siepaczów zepchnęli, mego brata z pokrępowania oswobodzili, sami oni na wóz wsiedli i do Bochni go, do cyrkularnego urzędu dostawili, a za dostawionego, jako nagrodę, sześć reńskich w cwancygerach na rękę odebrali, które Wojciech Cecuga między siebie i innych dwóch podzielił.

[s. 37] Gdy się to działo, między 12 a 4 godziną po południu, bratowa moja ze swemi dwoma córeczkami, Anną i Konstancyją, w kościele zamknięte, drżały od strachu i trwogi, nie wiedząc, co się ze mną i z ich ojcem dzieje. Gdy ta zgraja już odeszła, ja około kościoła tam i na powrót umyślnie po cmentarzu przechodzę, aby im dać poznać, że żyję. A gdy już pewny byłem, iż owi siepacze do domów popowracali, otworzyłem kościół, a jakoby życiem udarowany, powitałem drogie sercu memu osoby.

Uczciwego Augustyna Chmielka zostawiliśmy [s. 38] na noc na plebanii. $\mathrm{W}$ późną noc powraca fornal $\mathrm{z}$ wozem $\mathrm{z}$ Bochni i oznajmia, iż mego brata konwojowali poddani i że nie dopuścili na drodze krzywdy mu wyrządzić.

\footnotetext{
${ }^{61}$ Liplas - wieś w pow. wielickim, $5 \mathrm{~km}$ od Gdowa, $12 \mathrm{~km}$ od Wieliczki.
} 
Pani Ciepielowska kolatorka i dziedziczna pani Niegowici i Marszowic ze swoją przybocznią towarzyszką panną Mirecką, po stłuczonych ruchomościach we dworze, przenosi się na tymczasowne mieszkanie na wikaryjówkę, zaraz tego samego wieczora.

Znużony tak okrutnym kłopotem, bez rozbierania się, rzucam się na spoczynek. Serce bije silnie i gorączkowo...

\section{[s. 39] Dzień 25 lutego Popielec}

[tutaj kończy się tekst]

\section{Streszczenie}

\section{Rabacja chłopska 1846 roku w relacji ks. Jana Popławskiego z Niegowici}

Ocena wydarzeń z 1846 roku była różna w ocenie urzędowej austriackiej i patriotycznej polskiej. Według tej pierwszej wersji rzeź galicyjska była odruchem wierności włościan wobec monarchii austriackiej, potępiającym próbę powstania przeciw cesarzowi. $\mathrm{Z}$ polskiej strony rabację potraktowano jako skutek świadomej prowokacji dokonanej przez biurokrację austriacką, trafiającej na podatny grunt niechęci pańszczyźnianych chłopów wobec szlachty. Rabacja położyła kres przygotowaniom do narodowego powstania. Rozprzestrzeniła się w zachodniej Galicji, głównie w okolicach Tarnowa, Bochni i Jasła. Tzw. „krwawe zapusty” rozpoczęte ok. 19 lutego 1846 roku pochłonęły wiele ofiar. Chłopi napadali na dwory i plebanie w poszukiwaniu powstańców i broni, bili i mordowali dziedziców i ich oficjalistów, demolowali budynki, rabowali wyposażenie dworów i zabudowań gospodarczych.

Z tego okresu zachowały się relacje i wspomnienia, wśród nich relacja ks. Jana Popławskiego (1800-1892), ówczesnego proboszcza w Niegowici. Swoje wspomnienia spisał w 1857 roku, dla rodziny. Ich oryginał znajduje się w Bibliotece Naukowej PAU i PAN w Krakowie, podarowany w 1925 roku przez Seweryna Udzielę. Wspomnienia ks. Popławskiego z 22-24 lutego 1846 roku obejmują tylko 3 dni rabacji, mimo to są cenne 
jako kronikarski zapis wydarzeń w Niegowici i najbliższej okolicy. Zawierają też osobiste odczucia i komentarze autora wspomnień.

\section{Summary}

\section{The peasant slaughter of 1846 in the accounts of father Jan Popławski of Niegowić}

The evaluation of the events of 1846 differed in the opinions of Austrian officialdom and patriotic Poland. According to the version as assessed by the former, the Galician massacre was a reflex on the part of the peasantry loyal to the Austrian monarchy and condemning the uprising against the emperor. From the Polish side, it was viewed as the result of conscious provocation, on the part a bureaucratic Austria, which fell on the fertile ground of the villein peasants' malevolence toward the nobility and gentry. The slaughter put an end to the preparation for a national uprising. It spread through Western Galicia, primarily in the environs of Tarnów, Bochnia and Jasło. What has been dubbed 'the bloody carnival', which was launched around 19th February 1846, engulfed countless victims. The peasants fell on manor houses and presbyteries in search of insurgents and weapons, beating and murdering the country gentry and their clerks, demolishing buildings and robbing the manors and their farm outbuildings of furnishings and fittings.

Accounts and memoirs of that period have survived, amongst them those of Father Jan Popławski (1800-1892), the then parish priest of Niegowić. He wrote them for his family in 1857. The original, held in the Academic Library of the Polish Academy of Arts and Sciences and the Polish Academy of Sciences in Krakow, was gifted by Seweryn Udziela in 1925. Father Popławski's memoirs cover 22nd to 24th February 1846, encompassing only three days of the slaughter. For all that, they are valuable as a chronicler's record of events in Niegowić and its closest environs. They also contain the personal feelings and commentaries of their author. 